\title{
The Effect of School Environment and Extrinsic Motivation on Teacher Performance
}

\author{
Eka Octoviani \\ SMP Negeri 1 SP Padang \\ Email: ekafadly5@gmail.com \\ Syarwani Ahmad \\ Universitas PGRI Palembang, Indonesia \\ e-mail: syarwaniahmad@univpgri-palembang.ac.id \\ Nila Kesumawati \\ Universitas PGRI Palembang, Indonesia \\ e-mail: nilakesumawati@yahoo.com \\ Article History: Received on 17 November 2021, Revised on 20 January 2022 \\ Published on 28 January 2022
}

\begin{abstract}
The school environment is a physical and non-physical situation that occurs within the purview of the school. The school atmosphere is assisting instructors in developing motivation. As a result, the purpose of this study was to prove hypotheses regarding the effect of the school environment and extrinsic motivation on teacher performance. The quantitative descriptive approach was employed in the implementation of this research. The population is 125 persons, with 30 people serving as a trial sample and 95 people serving as the study's main sample. Data was collected through questionnaires, observations, and documentation approaches. In this study, data were analyzed using inferential statistics such as simple correlation tests, multiple correlation tests, t-tests, and f-tests Ogan Komering Ilir Regency, Jejawi District. According to the findings of the study, the school environment and extrinsic motivation have an impact on the performance of State Junior High School teachers in Jejawi District, Ogan Komering Ilir Regency, both partially and concurrently.
\end{abstract}

Keywords: School Environment, Extrinsic Motivation, Teacher Performance

\section{A. Introduction}

Education is designed to generate competent human resources. This entails possessing scientific knowledge or talents as well as decent manners, morality, or behavior. That is why education is supposed to yield outcomes rather than merely products (Muchtar, 2020). It is mentioned in order for the outcomes of the educational process to be able to maximize people's lives via the talents they possess. Not just learning information, but also engaging in the application of talents for the betterment of life.

This is consistent with the role of education as outlined in Law No. 20 of 2003 governing the national education system. That education serves to develop capabilities and shape the character and civilization of a dignified nation in the context of educating the nation's life, with the goal of developing students' potential to become human beings who believe and fear God Almighty, have noble character, are healthy, knowledgeable, capable, creative, independent, and become democratic and responsible citizens. 
Volume 3 (1) 2022

E-ISSN: 2723-6919 P-ISSN: 2746-0827

The implementation of national education has a very noble purpose, according to the set laws. It is not as simple as twisting the palm of the hand to attain this purpose. Of course, an integrated system is required so that all operations carried out are related to the fulfillment of the planned goals. The instructor or educator is an important factor that is also critical to the success of education. Because the majority of the essential duties, functions, and obligations associated with accomplishing national educational goals begin with the completion of instructional goals or learning objectives held in classrooms (Hamalik, 2007).

As a result, a teacher must optimize learning while also performing the primary activities and functions inherent in his professionalism. Teacher performance refers to the accomplishment of the teacher's task. According to Mangkunegara (2012), performance is a product of the job that has been completed. These outcomes might take the shape of improved quality or greater quantity. When referring to this description, it is apparent that he will be more dominating in enhancing the quality of learning implementation as an instructor. Although there are other amounts satisfied, such as learning materials and learning media generated by the instructor in carrying out their primary activities and functions.

The better the teacher's performance, it is considered that the better the final outcome. Such an assumption should be checked first, however it is absolutely plausible because anything done optimally yields greater outcomes. Although it cannot be overstated, there are several factors that must be addressed in order to achieve peak performance as a teacher (Pramesti \& Muhyadi, 2018). That is, a teacher's performance is influenced by variables other than the specific instructor in question.

According to Pramesti and Muhyadi (2018), various factors can influence teacher performance, including supervision, motivation, work atmosphere, and social position. In this study, the researcher assumes that the parameters mentioned in prior studies merit further investigation with modifications of additional variables. So that the previously examined work climate was described as a work environment in this study, and while before restricted to general work motivation, this research especially believes in the influence of extrinsic motivation.

The term "school environment" refers to anything that is under the purview of the school, particularly in terms of educational implementation. The school environment, according to Marini and Hamidah (2014), is a social environment (teachers and education staff, school friends and school culture) and a non-social environment (curriculum, programs, and infrastructure) in formal educational institutions that provide support for potential development learners. In general theory, this variable is more commonly referred to as the work environment. Because the school is also a place of employment for instructors.

As a result, the work environment may be defined as a gathering place under a range of settings and conditions that are not fixed or can vary. Sutrisno (2010) asserts that the work environment is everything linked to facilities and infrastructure for work operations that are around educators (as employees) when carrying out their major activities and functions and might impact work implementation. This work environment is also directly related to the place of work, all facilities, and equipment or equipment used to assist the work, the state of cleanliness of the room and its surroundings, adequacy of lighting, tranquility, and communication built by a group of people who are present at the work site. 
Volume 3 (1) 2022

E-ISSN: 2723-6919 P-ISSN: 2746-0827

According to Sedarmayanti (2011), the work environment is the entire tool, also known as the tools and materials possessed, the surrounding environment in which a person conducts his work, employs the proper way at work, and divides responsibility for the task being accomplished. As a result, it is apparent that the work environment is a significant influence in the execution of the task referred to as performance for a teacher at school.

According to the description, it is logical that the school environment is regarded as one of the aspects that might have an influence on teacher performance accomplishment. As a result, it is critical to demonstrate through empirical investigations. Furthermore, the purpose of this research is to demonstrate that extrinsic incentive can have a favorable influence on teacher performance. Motivation, as we all know, is the desire to do something. According to Putra and Frianto (2013), extrinsic motivation emerges as a consequence of factors from outside the person, such as an invitation, order, or compulsion from others, such that someone desires to do something in such a scenario.

As a result, it is evident that extrinsic motivation does not come from self-awareness, but rather from circumstances outside of the individual. As a result, the focus of this research is balanced since it investigates issues that are directly tied to elements outside of the instructor. The school environment is something that is there, and extrinsic motivation is the reason for doing something that is not motivated by self-awareness but by considerations of other variables.

A preliminary investigation was conducted as a reinforcement to carry out this research based on the researcher's original assumptions. According to the preliminary study's findings, the school atmosphere definitely differs. Because schools have varied customs depending on where they are located, especially in Jejawi District where schools are relatively far apart. As a result, the potential for disparities in teacher performance has been seen in the classroom setting. Similarly, extrinsic incentive is present in general. In certain schools, the principal was found to be constantly giving directives, reprimands, awards, and punishments for actions carried out by the school community. This is an example of extrinsic incentive, however not all of them are as strong as this. As a result, the possibility of disparities in the supply of extrinsic incentive between schools may be noticed.

Another area of interest for academics is the availability of documented learning completion by instructors in schools. Some teachers were found to have not appropriately recorded the completion of learning in terms of neatness and timeliness of collecting. This is a clear indicator that the teacher's performance is not yet at its peak. As a result, an in-depth investigation is required to discover additional aspects that may be vital to comprehend in order to identify the best answer to the difficulties that arise.

Based on this description, the researcher believes that it is necessary to conduct a study of the items described. This research was performed under the topic "The effect of the school environment and extrinsic incentive on teacher performance" to make the research more focused and the aims to be attained more obvious.

\section{B. Methods}

From April to August 2021, the research was carried out in a State Junior High School in Jejawi District, Ogan Komering Ilir Regency. The quantitative correlational research approach was applied in this study. According to Arikunto (2013), quantitative correlational research seeks 
Volume 3 (1) 2022

E-ISSN: 2723-6919 P-ISSN: 2746-0827

to identify whether there is a link between data or numerous factors. The factors in quantitative research in this study consist of the school environment (X1), extrinsic incentive (X2) on teacher performance $(\mathrm{Y})$.

Because Jejawi District has four public junior high schools, all instructors who work in these institutions are used as study subjects. The number of trial samples might be as high as 30 persons, while the primary sample for study implementation could be as high as 95 people. This study's data was gathered by questionnaires, observation, and documentation. The validity of the research instrument has been evaluated by expert evaluations and direct trials in order to gather reliable results. Similarly, in terms of dependability. Data analysis phases utilizing a basic linear regression test and a multiple linear regression test. Prerequisite tests, such as data normality, heteroscedasticity, and data multicollinearity, were first performed to reach this stage of analysis. The SPSS application is used to do automated statistical analysis at each level of the exam.

\section{Results and Discussion}

Descriptive understanding of each variable can be done comprehensively, so pay attention to the following table.

\begin{tabular}{lclllll}
\multicolumn{7}{c}{ Table 1. Descriptive Analysis of Data } \\
\hline & $\mathrm{N}$ & Range & Minimum & Maximum & Mean & Std. Deviation \\
\hline School Environment & 95 & 12,60 & 73,33 & 85,93 & 80,3816 & 3,14545 \\
Extrinsic Motivation & 95 & 15,56 & 73,33 & 88,89 & 80,6784 & 2,90260 \\
Teacher Performance & 95 & 14,82 & 72,59 & 87,41 & 79,8677 & 2,99134 \\
Valid N (listwise) & 95 & & & & & \\
\hline
\end{tabular}

The maximum score obtained for the school environment variable was 85.93, and the lowest was 73.33, resulting in a 12.60 range. The average value obtained in the varied school environment is 80.38 , with a standard deviation of 3.145 . The greatest value attained for the extrinsic motivation variable is 88.89 , with the lowest value being 73.33 , resulting in a range of 15.56. In terms of extrinsic motivation, the average reached is 80.68 , with a standard deviation of 2.90. The range of values for the dependent variable, teacher performance, was 14.82, with the greatest value being 87.41 and the lowest being 72.59. The average teacher performance variable score is 79.87 , with a standard deviation of 2.99 .

Because the significance value is $0.687>0.05$, and it is evident that the conditions for normality of data distribution have been satisfied, the data gathered from the research have been evaluated and certified normally distributed. Similarly, heteroscedasticity tests revealed that the data in this study did not exhibit heteroscedasticity symptoms because data points were dispersed above and below or around the number 0 ; data points did not accumulate precisely above or below; and the dispersion of data points was not structured. Another factor that was investigated was the data's multicollinearity, which showed that the data in this research did not exhibit signs of multicollinearity. This is based on the obtained tolerance value of $0.481>$ 0.10 and the VIF value of 2.078 10.0. As a result, the regression equation generated from this test is said to be satisfactory.

\section{The Influence of the School Environment on Teacher Performance}

The research sample's highest score is 85.93 , which is connected to their assessment of the educational environment. The quality of the school room, school infrastructure, security, 
Volume 3 (1) 2022

E-ISSN: 2723-6919 P-ISSN: 2746-0827

comfort, and relationships with the school community all contribute to the perceived school environment. The sample in this investigation reached the lowest value of 73.33. The sample size for stating that the school atmosphere is very excellent is just six persons, and this is based on a score of more than 85.00 . The highest score obtained by the study sample on the school environment was 82.22 , which was earned by as many as eighteen participants, or 18.9 percent of the whole research sample.

The sample group at SMP Negeri 4 Jejawi had the greatest average value for the school environment variable, 81.15, while the sample group at SMP Negeri 1 Jejawi had the lowest, 79.52. The difference in values obtained between the top and lowest is not statistically significant because it is just 1.63. Similarly, when the two values are classified, the greatest and lowest scores obtained are still included in the same category, namely the school atmosphere is considered to be good.

There is a substantial association between school environment characteristics and the performance of State Junior High School teachers in the Jejawi District, according to the study. This is demonstrated by the r-count value of $0.701>$ r-table 0.12017 , as well as the significance value of 0.0000 .05 . To put the t-count to the test again in order to show the statistical hypothesis's acceptance or rejection.

The t-value for the school environment variable is $9.475>1.986$, indicating that the alternative hypothesis (Ha) for testing the first hypothesis is accepted. As a result, the school atmosphere is said to have a considerable impact on the performance of state junior high school teachers in Jejawi District, Ogan Komering Ilir Regency. Another source of evidence for the acceptance of this alternative hypothesis is the significance value of 0.0000 .05 , which indicates that the alternative hypothesis (Ha) for $\mathrm{H} 1$ is accepted.

The correlation coefficient is 0.701 , indicating that the degree of the association between the school environment and teacher performance is 70.1 percent, classifying it as a strong relationship. The determinant coefficient is 0.491 , indicating that the size of the influence of the school environment variable on the performance of SMP Negeri teachers in Jejawi District is 49.1 percent, indicating a moderate to moderate effect.

The findings of this study also complement prior research, such as those of Marliya et al, (2020), who investigated the influence of the work environment on teacher performance in public junior high schools throughout Prabumulih Barat District. It is obvious that a positive work environment may contribute to a positive academic climate. As a result, it will be easier to maximize a teacher's professional performance. You might also consider the research of Angrainy et al, (2020), which focuses on the impact of the work environment on teacher performance. According to the findings of this study, the work environment has a considerable impact on teacher performance.

Similarly, Supardi (2014) claimed that a person's performance may be impacted by a variety of variables, one of which is the surroundings. Referring to the statement, it is evident that the findings of this study are consistent in terms of the elements that impact performance, because hypothesis testing has demonstrated that the environment has a substantial influence on teacher performance. According to Merry et al, (2020) and Susanti et al, (2021), a well-designed work environment can have a favorable and substantial influence on obtaining more optimal teacher performance. 
Volume 3 (1) 2022

E-ISSN: 2723-6919 P-ISSN: 2746-0827

As a result, it has become a challenge for a teacher to build a functional school district. As a result, the guru, as one of the school's principals, must be active in order to improve the school's surrounding environment. As a result, all activities become more enjoyable, with the primary goal of optimizing guru's own performance.

\section{The Effect of Extrinsic Motivation on Teacher Performance}

The most common figure was 81.48 , which was shared by as many as twelve participants, or 12.6 percent of the whole research sample. These values have been met in a satisfactory manner. The final score of the respondents was larger than 85.00, indicating that extrinsic motivation was placed in the extremely high group by eleven participants. The maximum score obtained by research participants in terms of extrinsic motivation was 88.89 , while the lowest score was 73.33 .

The average value for extrinsic motivation in each sample group suggests that it is classified as excellent, but no one has joined the very good category, therefore it is also a challenge in the field of education to engage in maximizing each extrinsic motivation indicator. These values vary quantitatively. In addition, the maximum score in the sample group is 81.32 at SMP Negeri 4 Jejawi, while the lowest score in the sample group is 79.93 at SMP Negeri 1 Jejawi. The difference in the two values is 1.39 , and it is considered not significant since the maximum and lowest values obtained by study respondents are in the same group, namely extrinsic motivation is strong or good.

There is a substantial association between extrinsic incentive characteristics and the performance of State Junior High School instructors in the Jejawi District, according to the study. This is demonstrated by the r-count value of $0.666>$ r-table 0.2017 , as well as the significance value of $0.000<0.05$. To put the t-count to the test again in order to show the statistical hypothesis's acceptance or rejection.

The extrinsic incentive variable has a t-count of 8.612. It is translated from this number as the t-table value, which is 1.986, which signifies t-count $>$ t-table; 8,612 >1,986. Based on this, the alternative hypothesis is accepted, implying that extrinsic motivation has a considerable influence on the performance of State Junior High School instructors in Jejawi District, Ogan Komering Ilir Regency. To corroborate these findings, a significance value of 0.0000 .05 is used, indicating that the alternative hypothesis $(\mathrm{Ha})$ is accepted and the statistical hypothesis (H0) is rejected.

The correlation coefficient value is 0.666 , indicating that the size of the association between extrinsic motivation and performance of State Junior High School teachers in the Jejawi District is 66.6 percent. The magnitude of the association is classified as strong. The determinant coefficient is 0.444 , indicating that the degree of the extrinsic motivation variable's effect on the performance of State Junior High School teachers in Jejawi District, Ogan Komering Ilir Regency is 44.4 percent and falls into the moderate to moderate influence group.

The findings of this study back up recent research by Diana, Ahmad, and Wahidy (2020), which found that work motivation had an impact on teacher performance. According to study done by Septiana, Fitria, and Kesumawati (2021), teachers' strong work motivation would give convenience in fulfilling each key duty, function, and responsibility of a teacher. 
Volume 3 (1) 2022

E-ISSN: 2723-6919 P-ISSN: 2746-0827

Harmendi et al, (2021), Alhusaini et al, (2020), and Arlita et al, (2020) all stressed that wellbuilt motivation by instructors may have a beneficial influence on the job they accomplish. As stated by Nabela et al, (2021), Umami et al, (2020), with strong motivation, teachers' work connected to their obligations would be improved.

The outcomes of this study are also confirmed by Gibson's hypothesis stated in Supardi (2014), which claims that psychological elements, one of which is motivation, can alter a person's performance. As a result, the outcomes of this study are consistent with Gibson's assertion that motivation is one of the elements influencing teacher performance. As a result, it is apparent that instructors must also be driven in order to become outstanding persons with great professionalism in delivering exceptional education.

\section{The Effect of School Environment and Extrinsic Motivation on Teacher Performance}

The greatest value produced by the research sample is a final score of 77.78 collected from as many as fifteen research samples. The majority of the participants in this survey believe that their performance is satisfactory. There are five persons who believe that teachers' performance in schools is excellent. This is well recognized, as evidenced by the purchase of values larger than 85.00. The highest score for teacher performance at Jejawi District public junior high schools is 87.41 . While the lowest final score for the teacher performance variable is 72.59 , it is still classified as good teacher performance.

The highest score was 80.31 at SMP Negeri 4 Jejawi. The sample group of SMP Negeri 1 Jejawi had the lowest score of 79.38. According to respondents' perspectives, the diversity of teacher performance is a type of accountability for each teacher for the things he has done. As a result, this research is also a type of self-evaluation for instructors in relation to the educational process, which is carried out in accordance with their primary obligations and functions as professionals.

There is F-count 55,151 > F-table of 3,095 indicating that the school environment and extrinsic motivation have a considerable impact on the performance of State Junior High School instructors in Jejawi District, Ogan Komering Ilir Regency. The significance value found, $0.000<0.05$, indicates that the alternative hypothesis $(\mathrm{Ha})$ is accepted and the statistical hypothesis $(\mathrm{H} 0)$ is rejected.

The score of 0.738 indicates that the school environment and extrinsic motivation have a considerable link with the performance of State Junior High School teachers in Jejawi District, Ogan Komering Ilir Regency, and so fall into the category of a strong relationship. The $\mathrm{R}$ Square column of 0.545 indicates that the school environment and extrinsic motivation have a considerable impact on the performance of State Junior High School teachers in Jejawi District, with a 54.5 percent influence and is classified as very influential.

The findings of this study also complement the findings of Marphudok et al, (2020), who discovered that the work environment and motivation might have a substantial impact on the attainment of higher teacher performance. Motivation and work environment factors are continuously able to have a favorable and substantial influence on getting improved performance, as noted by Fahmi and Hariasih (2016), Yani and Indrawati (2016), and Suryati et al, (2020), Tarmizi et al, (2021), Susmadiana et al, (2021), Astuti et al, (2020). 
Volume 3 (1) 2022

E-ISSN: 2723-6919 P-ISSN: 2746-0827

The outcomes of this study corroborate and reinforce Supardi's (2014) remark regarding teacher performance being impacted by a variety of factors, including individual ones such as motivation, as examined in this study. Similarly, situational aspects such as physical and occupational characteristics, including the work environment, must be considered. It is evident from this study that what is intended in the work environment is the school environment. As a result, instructors are expected to be able to maximize their ability for self-motivation, both internally and publicly. Similarly, the educational atmosphere is designed to reduce the likelihood of communication blunders.

\section{Conclusion}

The elements of the school environment and extrinsic motivation, either partially or concurrently, have a substantial impact on the performance of state junior high school teachers in Jejawi District, Ogarn Komering Ilir Regency.

\section{E. Acknowledgement}

Thank to the Principal of SMP Negeri 1 SP Padang, Rector Universitas PGRI Palembang, Director of Graduate Program and friends of graduate program educational management Universitas PGRI Palembang who have supported us to do this project.

\section{References}

Alhusaini, A., Kristiawan, M., \& Eddy, S. (2020). Pengaruh Motivasi Kerja dan Disiplin Kerja terhadap Kinerja Guru [The Influence of Work Motivation and Work Discipline on Teacher Performance]. Jurnal Pendidikan Tambusai, 4(3), 2166-2172.

Angrainy, A., Fitria, H., \& Fitriani, Y. (2020). Pengaruh Sarana Prasarana dan Lingkungan Kerja terhadap Kinerja Guru [The Influence of Infrastructure and Work Environment on Teacher Performance]. Journal of Education Research, 1(2), 154-159.

Arikunto, S. (2013). Prosedur Penelitian Suatu Pendekatan Praktik [Research Procedure A Practical Approach]. Jakarta: Rineka Cipta.

Arlita, S. E., Ahyani, N., \& Missriani. (2020). Pengaruh KompetensiAkademik dan Motivasi Guru Terhadap Kinerja Guru [The Effect of Academic Competence and Teacher Motivation on Teacher Performance]. Attractive: Innovative Education Journal, 2(3), 814.

Astuti, R. W., Fitria, H., \& Rohana, R. (2020). The Influence of Leadership Styles and Work Motivation on Teacher's Performance. Journal of Social Work and Science Education, 1(2), 105-114. https://doi.org/10.52690/jswse.v1i2.33

Fahmi, A., \& Hariasih, M. (2016). Pengaruh Motivasi, PengalamanKerja, dan Lingkungan Kerja terhadap Prestasi Kerja Guru SMK Muhammadiyah 1 Ngoro Jombang [The Influence of Motivation, Work Experience, and Work Environment on Work Achievement of Teachers at SMK Muhammadiyah 1 Ngoro Jombang]. Jurnal Bisnis, Manajemen \& Perbankan, 2(2). 
Hamalik, O. (2007). Proses Belajar Mengajar [Teaching and learning process]. Jakarta: Bumi Aksara.

Harmendi, M., Lian, B., \& Wardarita, R. (2021). Pengaruh Gaya Kepemimpinan Kepala Sekolah dan Motivasi Kerja Terhadap Kinerja Guru [The Influence of Principal's Leadership Style and Work Motivation on Teacher Performance]. PRODU: Prokurasi Edukasi Jurnal Manajemen Pendidikan Islam, 2(2).

Law No. 20 of 2003

Mangkunegara, A. P. (2012). Manajemen Sumber Daya Manusia [Human Resource Management]. Bandung:Remaja Rosdakarya.

Marini, C. K., \& Hamidah, S. (2014). Pengaruh Self-Efficacy, Lingkungan Keluarga, dan Lingkungan Sekolah Terhadap Minat Berwirausaha Siswa SMK Tata Boga [The Influence of Self-Efficacy, Family Environment, and School Environment on Entrepreneurial Interests of Culinary Vocational High School Students]. Jurnal Pendidikan Vokasi, 4(2), 195-207.

Marliya, Fitria, H., \& Nurkhalis. (2020). Pengaruh Sarana Prasarana danLingkungan Kerja terhadap Kinerja Guru Di SMP Negeri se-Kecamatan Prabumulih Barat [The Influence of Infrastructure and Work Environment on Teacher Performance in Public Junior High Schools in West Prabumulih District]. Journal of Education Research, 1(3), 206-2012.

Marphudok, Lian, B., \& Fitria, H. (2020). Pengaruh Lingkungan Kerja dan Motivasi Kerja terhadap Kinerja Guru SMA di Kecamatan Muara Padang [The Effect of Work Environment and Work Motivation on the Performance of High School Teachers in Muara Padang District]. Jurnal Intelektualita:Keislaman, Sosial dan Sains, 9(1), 167178.

Merry, Harapan, E., \& Rohana. (2020). Kinerja Guru Ditinjau dari Pengaruh Lingkungan Kerja dan Penghargaan [Teacher Performance Judging from the Effect of the Work Environment and Awards]. Jurnal Ilmiah Bina Edukasi, 13(1), 27-40.

Muchtar, S. A. (2020). Pendidikan Ilmu Pengetahuan Sosial (Paradigma Revitalisasi dan Inovasi Pembelajaran) [Pendidikan Ilmu Pengetahuan Sosial (Paradigma Revitalisasi dan Inovasi Pembelajaran)]. Bandung: Gelar Pustaka Mandiri.

Nabela, S., Fitria, H., \& Nurkhalis. (2021). Pengaruh Kompetensi Profesional dan Motivasi Kerja Guru Terhadap Kinerja Guru [The Influence of Professional Competence and Teacher Work Motivation on Teacher Performance]. ISEJ: Indonesian Science Education Journal, 1(2).

Pramesti, D., \& Muhyadi. (2018). Faktor-Faktor Yang Mempengaruhi Kinerja Guru SMA [Factors Affecting High School Teacher Performance]. Harmoni Sosial, 5(1), 43-56.

Putra, A. K., \& Frianto, A. (2013). Pengaruh Motivasi Intrinsik dan Motivasi Ekstrinsik Terhadap Kepuasan Kerja [The Effect of Intrinsic Motivation and Extrinsic Motivation on Job Satisfaction]. Jurnal Ilmu Manajemen, 1(1), 377-387. 
Sedarmayanti. (2011). Manajemen Sumber Daya Manusia [Human Resource Management]. Bandung: Refika Aditama.

Supardi. (2014). Kinerja Guru [Teacher Performance]. Jakarta: Raja Grafindo Persada.

Suryati, Harapan, E., \& Houtman. (2020). Effect of Work Motivation and Work Climate on Teacher's Performance. International Journal of ProgressiveSciences and Technologies, 20(2), 137-144.

Susanti, E., Ahyani, N., \& Missriani. (2021). Pengaruh Lingkungan Kerja dan Kepemimpinan Kepala Sekolah Sebagai Supervisor Terhadap Kinerja Guru [The Influence of the Work Environment and Principal's Leadership as a Supervisor on Teacher Performance]. Jurnal Pendidikan Tambusai, 5(1), 1440-1448.

Susmadiana, S., Lian, B., \& Puspita, Y. (2021). The Effect of Managerial Supervision and Work Motivation on Improving Principal's Performance. Journal of Social Work and Science Education, 2(2), 181-187. https://doi.org/10.52690/jswse.v2i2.248

Sutrisno, E. (2010). Manajemen Sumber Daya Manusia [Human Resource Management]. Jakarta: Kencana.

Tarmizi, A., Lian, B., \& Puspita, Y. (2021). The Influence of Organizational Culture and Motivation on Employee Performance. Journal of Social Work and Science Education, 2(2), 109-116. https://doi.org/10.52690/jswse.v2i2.230

Umami, S., Lian, B., \& Missriani. (2020). Pengaruh Kepemimpinan dan Motivasi Kerja Guru Terhadap Disiplin Kerja [The Influence of Teacher Leadership and Work Motivation on Work Discipline]. JMKSP (Jurnal Manajemen, Kepemimpinan, dan Supervisi Pendidikan), 52-66.

Yani, A., \& Indrawati, A. (2016). Pengaruh Lingkungan Kerja dan Motivasi Kerja terhadap Kompetensi Guru Bersertifikasi di SMK Negeri 1 Pasuruan [The Influence of Work Environment and Work Motivation on Certified Teacher Competencies at SMK Negeri 1 Pasuruan]. Jurnal Pendidikan Bisnisdan Manajemen; 2(1). 